\title{
ILCEA
}

Revue de l'Institut des langues et cultures

d'Europe, Amérique, Afrique, Asie et Australie

43 | 2021

Images des Amériques : fabrique, représentations, usages

\section{The Representations of British North America in the British Press after the American Revolution}

(c. 1783-1815)

Les représentations de l'Amérique du Nord britannique dans la presse

britannique après la Révolution américaine (c. 1783-1815)

\section{Alice Lemer-Fleury}

\section{OpenEdition}

\section{Journals}

Electronic version

URL: https://journals.openedition.org/ilcea/13135

DOI: 10.4000/ilcea.13135

ISSN: 2101-0609

\section{Publisher}

UGA Éditions/Université Grenoble Alpes

\section{Printed version}

ISBN: 978-2-37747-299-4

ISSN: 1639-6073

Electronic reference

Alice Lemer-Fleury, "The Representations of British North America in the British Press after the American Revolution (c. 1783-1815)", ILCEA [Online], 43 | 2021, Online since 30 June 2021, connection on 02 July 2021. URL: http://journals.openedition.org/ilcea/13135; DOI: https://doi.org/10.4000/ilcea. 13135

This text was automatically generated on 2 July 2021.

(c) ILCEA 


\title{
The Representations of British North America in the British Press after the American Revolution (c. 1783-1815)
}

\author{
Les représentations de l'Amérique du Nord britannique dans la presse \\ britannique après la Révolution américaine (c. 1783-1815)
}

Alice Lemer-Fleury

\section{Introduction}

In 1783, as the Treaty of Paris acknowledged the independence of the thirteen colonies, the British Empire in North America was reduced to the under populated and underdeveloped provinces of Nova Scotia and Quebec-the latter, conquered from France only two decades before, was often derided for being little more than, as Voltaire had put it, "a few acres of snow" (Simpson-Housley \& Norcliffe, 1992: 1). It was a widely held view in the early 1780s that the Empire had been amputated of its most valuable possessions, that "the sun of England might be said to have set" indeed (the Earl of Shelburne, The Parliamentary Register, vol. VIII, 1782: 366) and that the most northerly British possessions in North America would never compensate for such a loss. ${ }^{1}$ However, the remaining colonies increased in political importance as well military and economic consequence to the British Empire as they became the only British possessions in North America and the new home of thousands of American Loyalist refugees who had fled the United States (Knowles, 2006: 36; Jasanoff, 2010: 46). To put it in the words of the Secretary of State "the few Provinces which we have now remaining on that side of the Atlantic, of course increase in consequence to this Country" (Sydney to Parr, 29 May 1784, NAC, A105:38), and this led to the implementing of several important reforms and decisions ${ }^{2}$ aimed at securing British 
possession of British North America and developing the economic and military potential of the colonies.

2 The aim of this article is thus to try to assess and understand how the increasing importance of British North America after the loss of the thirteen colonies was translated to the eyes of the British public. What were the images of British North America forged in the minds of the Britons? How were the colonies represented in Britain after 1783 and to what purpose?

The history of British North America within the British Empire at the end of the Long Eighteenth century has not attracted much scholarly interest, especially for the period after $1790 .{ }^{3}$ Besides, though research does exist both on the representations of the thirteen colonies in Britain and on the importance and omnipresence of the Empire at home (Wilson, 1994; Hall, 2008), ${ }^{4}$ there remains a gap in the historiography as far as British North America is concerned-and works on the ways in which Britons envisioned and imagined their North American colonies after 1783 are inexistent. ${ }^{5}$

4 The scope of this paper is limited to the British press ${ }^{6}$ because newspapers offered a rather comprehensive (though not exhaustive) digest of the ideas, opinions and representations that were put forward and developed in other public and published sources, such as parliamentary debates, economic works, pamphlets written by promoters, travel writers, reviews and magazines. The press was a tool to convey the official propaganda, yet, since editors relied on advertising revenues, they also had to attract readers. As a result, the late Eighteenth-century press reflected both the official propaganda and the interests of British readers (Williams, 2010: 105-149; Black, 1992: 13-23; Schweizer: 32-48). It is also interesting to study the British press because it attracted more readers than other published sources. Though it is impossible to assess with minute accuracy the readership of British newspapers in the late Eighteenth century, it is certain that it was rather large and expanding. Indeed, from the late $1780 \mathrm{~s}$ on, the Post Office improved the distribution of newspapers-which thus reached a larger public. The number of tax stamps issued (which increased from 12.6 million in 1775 to 16 million in 1801) shows that newspapers were more and more largely distributed throughout Britain. Besides, a newspaper bought could be read by several readers: papers were for example distributed and accessible in coffee shops, barbershops, taverns and inns. The literacy rate was increasing and those who could not read had the papers read to them since reading was a sociable activity in the late Eighteenth century. As a result, a large and increasing portion of the population, not only the aristocracy or the upper middle class, had access to what was written in the press (Williams, 2010: 105-149; King, 2007; A Newspaper History, 1935: passim).

5 Therefore, through the study of London-based and local newspapers, magazines and reviews published both in England and in Scotland at the end of the Long Eighteenth century (from the end of the War of Independence in 1783 to the end of the War of 1812 in 1815), this paper shows how Nova Scotia and the Canadas were represented to the British public and thus gives some insight into the ways Britons must have imagined their possessions in North America. It also explores the manners in which those images of North America contributed to the spreading of the imperial propaganda in the British public sphere-by idealising the vision of British North America whilst, in the meantime, attempting to destroy the image of the United States as a land of plenty, freedom and opportunity. 


\section{Representations of British North America in the British press}

6 The analysis of British papers shows that British North America was not the main concern for editors or readers, as it ranked behind more pressing and sensationalist issues such as Revolutionary France, the United States, India (with the trial of Hastings) or the West Indies. However, news from and articles about the Canadian colonies were regularly published. The articles on British North America that were published in the British press took several forms such as short news items, pieces quoting official gazettes, extracts of parliamentary debates, letters from "correspondents" in the colonies, letters to the editors as well as adverts. Most of the time, articles first appeared in London-based papers and were then reprinted in local papers, thus spreading the representations of British North America throughout England and Scotland.

\subsection{A sterile land of dangers}

7 The British press did not at first convey a very positive image of British North America, especially at the beginning of the period under study. In the early 1780 s, it was not unusual to have a gloomy image of the state of the British Empire in North America depicted in the press. In 1785, for example, a dismayed observer wrote to the Gentleman's Magazine in order to offer his bleak vision for the future of the British Empire, stating:

The Sun of Britain's glory is set [...]

In 1763 - The British dominions extended from the North Pole, or, to narrow the view, from the northern parts of Hudson's Bay to Cape Florida-a stretch of continent of 2500 miles-from the frozen to the torrid zone.

In 1783 - The British dominions in America are confined to the northern provinces of Canada and Nova Scotia, with the lesser part of the three great lakes, the proud British nation having been stripped of all the rest [...]. (The Gentleman's Magazine, vol. 55, 1785: 790) [italics in the original]

8 Such pessimism conveyed in this example reflected the idea that the remaining British colonies in North America were not and would never be a valuable asset for the Mother Country. These grim and dreary representations of British North America largely emanated from observers and contributors who had a pecuniary or political interest in having the colonies depicted in a derogatory manner. The idea that the British Empire had been dismembered off of their most valuable colonies was reinforced by the West Indian lobbies. The merchants who traded in the Caribbean did not want their commerce to be limited to British North America only, thus in order to show that the United States must not be excluded from British trade by virtue of the Navigation Acts, they portrayed the remaining British colonies as wild, frozen, inhospitable, sterile lands (Champion, 1784: 108; A Free and Candid Review of a Tract entitled "Observations on the Commerce of the American States", 1784: 8-16, 23-25, 80-88; Edwards, 1793: 417). Their representations were thereafter found in the press (The Times, 18 Feb. 1785, 26 Jul. 1785, 5 Jul. 1790).

9 Those who, for diverse socio-economic reasons, lobbied against the emigration of Britons across the Atlantic constituted another set of observers who tried to convey the idea that British North America was a hostile land. Those who deplored that many 
British (and especially Scottish) migrants left Britain for the colonies did not only focus on the image of a frozen desert, they also tended to depict the Canadian colonies as a land of dangers and strangeness. It was therefore not uncommon to have articles published about the hazards of the transatlantic crossing, ranging from piracy to shipwrecks, sea storms or epidemics on board (The Times, 3 Apr. 1787, 20 Feb. 1793, 19 Jan. 1808, 26 Sept. 1811, 26 Jan. 1815). In the 1790s, when the emigration flows increased, some articles detailed the harsh living conditions of the new settlers (The Times, 23 Mar. 1790, 5 Nov. 1795), with a slight focus on epidemics and food shortages (Derby Mercury, 29 Jul. 1784, 18 Mar. 1790) ${ }^{7}$ most certainly in an attempt to scare off potential migrants. In the first decades of the Nineteenth century, the articles on emigration tended to highlight the difficulties faced by indigent migrants when they arrived in the colonies. The views of some local observers, who lamented the lot of these newcomers who had been promised wonders, were printed in British papers:

The poor ignorant wretches are deluded, by false and exaggerated accounts of the Island [Prince Edward Island], to quit, perhaps, comfortable situations at home [...] they are turned out on a beach, without a place to shelter themselves in, except an old windmill, which is used by Government as a telegraph, and is pervious to every blast! (The Times, 9 Nov. 1810)

10 The purpose of these writers was to convey the idea that migrants would only find a life of hardships and misery in the colonies. Other observers denounced the conditions aboard migrant ships and the pitiful state of migrants who landed in the colonies; for instance, a letter published in The Times explained how "the wretched creatures [were] most dreadfully treated on the passage" (The Times, 24 Jul. 1815). Though less numerous (Bickham, 2013: 250-253), articles detailing the behaviour of Natives in the colonies must also have had a terrifying effect on British imagination. Sometimes described as "hostile" "warriors" who would attack, murder or scalp settlers, these articles made clear that it was important to maintain good relations with the native tribes, especially those at the US-Canada border, in order to keep them as allies (The Times, 12 Oct. 1785, 27 Mar. 1792, 22 Oct. 1793). ${ }^{8}$ This image of danger and harshness, aimed at creating wariness and even fear, was reinforced by frequent reports on the weather conditions in the colonies: the snow, the cold and the severity of winters were part of the daily lives of those who lived and settled in the colonies, and the press cultivated such a representation in the imagination of Britons with short reports, especially when winters were very harsh, or when summers were particularly dry and arid (The Times, 19 Apr. 1790, 8 May 1795, 26 Sept. 1796, 22 Jun 1805, 7 Aug. 1810, 22 Sept. 1815). ${ }^{9}$

11 However, as the terms of trade with the United States were settled (though only for a while) and emigration became a less pressing issue with the resumption of war against France, such representations became rarer and rarer. They could still be found sporadically, as in this example from the Annual Review, when one of the contributors affirmed:

Canada, the fragment which we have contrived to save from the wreck of our great American Empire; Canada appears respectable in a map of the British territories to those who can forget the past; and it is indeed conspicuous for its lakes, and its number of square miles. But to us this land of ice, and beavers, and rattlesnakes, excites but little national interest. (The Annual Review, vol. 3, 1805: 194-195) ${ }^{10}$

Yet such scathing criticism were early on taken over by the more numerous and widespread articles that promoted a decidedly more positive image of the colonies. 


\subsection{Land of plenty, land of opportunity}

The study of the press shows that the positive representations of British North America originated in a more diverse set of writers and observers who depicted the colonies as a place quite akin to heaven on Earth. First, the British press frequently pictured British North America as a land of plenty. Such a representation was mostly, though not exclusively, focused on the Maritimes in the 1780s when the promoters of the colonies attempted to destroy the gloomy representations put forward by the West Indian lobby. For instance, in 1784, an article explained:

In the great Question, whether the remaining British Colonies in America are capable of providing the West Indies with Provisions and Lumber, it was stated to the Committee of the Privy Council, that, besides the Capacity of Canada and NovaScotia, there are 1,5000,000 acres in the Islands of Cape Breton, capable of producing any Sort of European Grain, and remarkably fit for Garden Vegetables, and that though the Coast is subject to Fogs, the Centre is dry. That it abounds with Lumber, Pine of every Dimension, Oak of various Kinds, ash and Elm, Beech, Birch, and Maple [...] - and that they did not doubt but Lumber of every Kind, in sufficient Quantities, could be found in Canada, Nova-Scotia, and Cape Breton [...]. (Oxford Journal, 4 Sept. 1784) ${ }^{11}$

It became more common to read this type of accumulation highlighting how British North America abounded in all sorts of resources that were essential to the economy (grains for example) and defence (with timber for the navy) of the Mother Country. Such a representation of the Maritime colonies then spread to Lower and Upper Canada from the 1790s onwards and became particularly prominent during the penury of 1795 during which the Canadas provided Britain with important numbers of bushels of wheat (see for instance: Norfolk Chronicle, 18 Jul. 1795; Chester Courant, 24 Jul. 1795; Northampton Mercury, 25 Jul. 1795). Through to the 1810s, British papers thus mostly showed British North America as a land of plenty which afforded countless sources of riches for the soils were fertile, the fisheries productive, the fur trade flourishing while its grounds abounded with ores (notably iron) and its forest with timber for the ship yards. ${ }^{12}$

14 In the advertisement sections, where lands in the colonies were put up for sale, this image of British North America was reinforced and made even more idyllic. These descriptions showed it both as land of abundance and as land of (economic) opportunity; this is the case, for example, of this ad for a lot for sale on Prince Edward Island, which appeared in The Times in 1807:

A healthy and temperate climate. The soil is extremely fertile, and produces, with little labour all kinds of grain in perfection, hemp, flax, potatoes, and vegetables. The timber, in general, consists of oak, pine, beech, large hemlock (the nark of which cannot be excelled for tanning), spruce, yellow birch, black birch, curled and bird's eye maple, which makes very handsome furniture, and the maple produces sugar of excellent quality; the rivers afford salmon, eels, carps, smelts, \&c. and the bays contain oysters, lobsters, and other shell-fish; the country abounds with wild fowl, hares, and partridges. [...] no place is better calculated for the India market; as it abounds with horses, black cattle, sheep and hogs, lumber; barrel hoops, staves, and every other article fit for exportation to the West Indian Islands; it is also particularly suitable to the brewery and distillery business, as hops grow here luxuriantly; the finest barley to be had very cheap, and spirits, for which there is a very great demand, sell dear. [...] This island is very desirable to British settlers, being part of the British Empire, and possesses all the means of living with cheapness and comfort. (The Times, 20 Oct. 1807) 
Once again accumulations were used to depict British North America as a land of plenty, where one could prosper. Thus, ads for lands both in the Maritimes and in the Canadas, contributed to the spreading of the image of the colonies as a land of abundance-where all sorts of timber and crops could be grown-but also as a land of economic opportunity, where one could prosper if they were willing to work. ${ }^{13}$ Newspapers also duly published the names of the officials appointed to more or less prestigious positions in the colonial administration, the colonial judicial branch or the imperial army on a regular basis thus reinforcing the idea that British North America could be a place where the lesser aristocrats (especially the younger males who did not inherit titles or family estates) could thrive. ${ }^{14}$ This representation was not however confined to those who could afford large estates across the Atlantic. Indeed, advertisements for all sorts of jobs, such as domestic workers to accompany a wealthy family in the colonies, miller, cooper, or in the Navy, were frequently published ${ }^{15}$ thus targeting the working and indigent classes.

\subsection{Land of loyalty}

Not only did papers regularly publish articles insisting on the economic and agricultural potential and healthy development of the colonies but they also swarmed with articles, letters and official dispatches underlining how "all [was] well in Canada" or "everything [was] quiet" in Upper or Lower Canada or Nova Scotia. These short pieces of news thus tended to portray the colonies as a haven of peace and tranquillity. ${ }^{16}$ In the 1780s, however, when the newly-arrived Loyalists and a small part of the French-speaking bourgeoisie and sent petitions to demand constitutional reform for the province of Quebec,$^{17}$ some fears were voiced in Britain, in The Times for instance, as a contributor explained: "It is much to be feared that this spirit of liberty, or rather independence, will yet cause come disturbances in other of our colonies." (The Times, 22 Apr. 1785$)^{18}$ These fears were nevertheless short-lived as it became clear that the colonists were not seeking independence from the British Empire, but instead, demanded institutions modelled on those of the Mother Country. And on the whole, the press tented to depict the colonists as loyal and faithful subjects. English-speaking settlers enjoyed a positive image both in Parliament and in the press. Like MPs, the newspapers were unanimous in their praise of the Loyalists and their desire to reward those men who had lost so much because of their "loyalty to His Majesty" and their "attachment to the British Government" (The Parliamentary History, 1788-1789, vol. XXVII: 610-620). As The Times summed up: "the advantages which are expected to accrue to this country, from settling a number of faithful friends, strongly attached to our happy condition, are infinite" (The Times, 24 May 1786). In the 1790s, after the passing of the Canada Act which granted the newly-created colonies of Upper and Lower Canada constitutions somewhat modelled on that of Great Britain, the press even conveyed a sense of pride in the possession of British North America. ${ }^{19}$ This excerpt from the Caledonian Mercury in 1793 summarizes the positive representation that was spread in the British papers:

A private letter from Canada gives the pleasing intelligence, that the people of that province, while a great part of the world are involved in warfare, are at the present time enjoying all the comforts and even the luxuries of peace. Many families are enriching themselves by their industry; their exports are very considerable, particularly their furs to England; they have sowed, and are still sowing, prodigious 
quantities of timber for various uses; and owing to recent improvements in agriculture, such has been the quick fertility of their vegetation, that seed sown in May has sprung up into full crops, cut down, and carried into the barn in August. Enjoying all the privileges of the British Constitution, the Canadians are contented and happy. (Caledonian Mercury, 10 Jun. 1793)

British North America was represented as a fertile, promising, blessed and faithful land where the loyal subjects of the King could enjoy all the rights and privileges of Englishmen-a land that thus somehow also belonged to the national community. In the decades to come, the acts of loyalty and gestures displaying the attachment of the Canadians to the British Crown and Parliament were duly reported in the press, especially when Great Britain was at war against France (from 1793 to 1802 and from 1803 to 1815). In 1807, for example, the British press reported that a monument to Lord Nelson's glory had just been inaugurated in Montreal. The inscription on the pedestal read: "England expects every man to do his duty." (Morning Post, 8 Aug. 1807) This symbolic gesture, showing how the North American colonies belonged to the national community and supported the Mother Country in the war against Napoleon, was also spread in the local papers (Bath Chronicle and Weekly Gazette, 13 Aug. 1807; Kentish Gazette, 14 Aug. 1807; Northampton Mercury, 15 Aug. 1807; Ipswich Journal, 15 Aug. 1807; Hereford Journal, 19 Aug. 1807; Derby Mercury, 20 Aug. 1807). The War of 1812 continued to strengthen this image of loyalty, as the British press celebrated the zeal and dedication of the Canadian settlers in their fight against the United States. The Prince Regent's speeches highlighting the settlers' attachment to the motherland and their efforts to counter the enemy's attacks were circulated in the press, so were reports celebrating "the purely British sentiments" that drove the Canadians and congratulating "our brave subjects and soldiers of Canada" (The Times, 1 Dec. 1812, 26 Jun. 1813, 27 Jul. 1813). ${ }^{20}$

On the whole, the representations of British North America in the British press were thus largely positive as the colonies were mostly presented as a land of plenty, opportunity and loyalty that Britons could be proud of possessing and defending-and somewhat overshadowing the less numerous articles that gave a negative image of the colonies. This could be explained by the fact that the pro Canadian lobby, which attempted to promote the different provinces at home to gain more subsidies, advantages or migrants, became more active in Britain throughout the period 17831815 , but it could also be linked to the fact that the positive representation of British North America was intrinsically connected to the government's imperial ideology.

\section{Spreading the imperial propaganda}

Indeed, the favourable representations of British North America were both a reflection of the imperial propaganda and ideology as well as a means that contributed to spread it further all across Britain.

\subsection{Trade and constitution: the representations of British North America and the diffusion of the colonial doctrine}

If the Canadian colonies appeared as a land of plenty in the British press, it was because a large majority of the articles published dealing with British North America focused on 
trade and international relations (which were linked to commerce, as the fur trade, the fisheries and timber for example weighed heavily on international relations). In the colonial doctrine and in the colonial policies implemented by the British government, colonies were essential to the expansion of trade for the benefit of the metropolis (Commissions and Instructions to Governors, 1778-1861, NAC, MG40B, Doughty, 1905: 261-285; Doughty, 1906: 3-69). Britons, who were both investors in colonial trade and consumers of colonial products, closely followed the development of the Canadian colonies and their economic potential. Most articles remained quite vague, describing the Canadian commerce as "valuable" or "important", though some went into further details, ${ }^{21}$ yet the countless "ship news"-which enumerated the goods coming from the colonies shipped to British ports-, reports, letters and articles on colonial trade first and foremost tended to emphasise the importance of the Canadian trade to the British economy within a protectionist system. MPs regularly debated and legislated over trade (ranging from the Navigation Acts, the incentives through premiums for example or the raising or suppression of taxes) and these debates were partially published or summarized in papers. ${ }^{22}$ This was a means of hammering in and disseminating the procolonial and protectionist propaganda: what mattered was that the colonial trade had to be developed and encouraged for the commercial benefit of the Mother Country. Such a tenet pervaded most of the public debate and was deeply entrenched in the ways British papers tackled colonial issues, so that, in 1790 for instance, when Parliament was about to discuss the new constitution for the Province of Quebec, one could read in local papers:

Among the several objects of commerce, which are intended to be improved by means of this laudable establishment, an extension of the Fur trade is the most considerable, but great profits are expected from the iron and timber of the province. (Kentish Gazette, 10 Dec. 1790) ${ }^{23}$

Thus emphasising how almost every single Canadian topic was regarded through the lens of trade and profits (whilst underlining the economic potential of the North American colonies once more).

The press also spread the idea that colonial possessions were essential in international relations. This was especially true during the Napoleonic Wars, during which the British press insisted that the possession of British North America gave Britain an edge over France, and that the French Emperor would try to attack and conquer them (Morning Chronicle, 17 Jun. 1805). ${ }^{24}$ Similar ideas were spread during the War of 1812, when, for example, a reader writing to The Times explained: "that Canada may be ultimately wrested from us, is a conclusion too mortifying to be willingly admitted" while insisting on the commercial and strategic importance of the North American colonies-notably Quebec, "the Gibraltar of the new world" (The Times, 17 Aug. 1814).

The spreading of British values and principles, another pillar of the colonial doctrine, was also achieved through articles that dealt with the British North American colonies. It was closely linked to the representation of British North America as a set of loyal and faithful colonies. This was particularly the case after the Canada Act was passed in 1791. In the years that followed, the press emphasized its pride in British institutions and congratulated itself for this constitution. In April 1793, the Leeds Intelligencer wrote:

The New Constitution of Canada meets with the most perfect approbation of all the inhabitants. They have in consequence, transmitted home addresses to the King, expressive of their gratitude and loyalty. (Leeds Intelligencer, 29 Apr. 1793) 
(1) on migrants who chose British North America over the United States, ${ }^{25}$ what is however certain, is that when press articles tackled the issue of emigration, most of the time, they clearly tended to promote the British colonies whilst attempting to destroy the image of the United States. As the press gave to see an idyllic, almost heavenly Canada, it pictured the former colonies in hellish terms. In the 1780s and 1790s in particular, the press revelled in the difficulties of the Confederation, which led to emphasize (directly or indirectly) the superiority of the British colonies. It was therefore quite common to have articles on Americans who left the United States to seek shelter in the British colonies (The Times, 2 Feb. 1786). ${ }^{26}$ This type of articles both derided the former colonists as ungrateful rebel children running back begging for the protection of the Mother Country and strengthened the image of Canada as a haven of peace and tranquillity. From the 1800s onwards, letters from the colonies published in British papers began to focus on the lot of migrants and typically affirmed that the United States were a land of white slavery and prostitutions for settlers who chose them while, in the meantime:

How very different is the situation of those emigrants who land in Canada or in Nova Scotia. If they have a passage to pay for, they work for it as creditors, not as slaves, being protected by the same paternal government which rules the mother 
country [...] and if sober and industrious, but few years are requisite to be quietly and comfortably settled. [...] Besides, in British America, the climate is healthier, and the yellow or putrid fevers entirely unknown, and provisions, of every description, sell 50 to 80 per cent cheaper than in the United States! (Kentish Gazette, 25 Sept. 1804; Hampshire Chronicle, 1 Oct. 1804) ${ }^{27}$

This type of articles portrayed the British colonies as superior in all respects to the United States, and through their attempt to denigrate the former colonies, they contributed to reinforcing the positive representations of the Canadian colonies and promoted them all across Britain.

\section{Conclusion}

The representations of British North America in Great Britain at the end of the Long Eighteenth century were not unanimously idyllic, but they were on the whole mostly positive and favourable. This image of the British colonies as a land of plenty, of opportunity, of liberty both sprang from and helped diffuse the imperial propaganda of the Government and of Canadian promoters, whilst denigrating and attempting to destroy the image of the United States. As a result, the images of Canadas that were being constructed in the British psyche through the press was less an attempt at a faithful depiction of British North America than a means to promote and diffuse British imperialism across the Atlantic.

Such a positive representation did not, however, stand the test of time. In the later Nineteenth century, the depiction of Canada in Britain became more nuanced, as Simpson-Housley and Nordcliffe note "the image of Canada that has been constructed by its iconographers is far from edenic", while that of the United States was, on the contrary akin to "earthly paradise" (Simpson-Housley \& Nordcliffe, 1992: 2). And indeed, scholarly research on the representations of Canada in the later Nineteenth century indicates that sources, whether they be intended for adults of children, reflected both the advantages and difficulties of life in British North America and represented it in a less simplistic (or dare we say Manichean) and more realistic manner (Kitzan, 2001: 20; Edwards \& Saltman, 2010: 18-21).

Yet, that the descriptions of British North America in the British press after the American Revolution were not exactly accurate nor true to life, and less so than those of the Nineteenth century, may actually be immaterial. Whether it was a means to reinforce attachment to British North America or boost the pride and morale of the population in a period of ongoing conflicts, what these representations really show is a clear reflection of Britons at the end of the Long Eighteenth century-their obsessions for commerce, defence and the diffusion of their principles-which contributed to "forge" Britishness around the possession of an overseas Empire (Colley, 1992). 


\section{BIBLIOGRAPHY}

\section{Primary Sources}

\section{Newspapers}

studied from 1783 to 1815 on: <https://www.thetimes.co.uk/tto/archive/> and <https:// www.britishnewspaperarchive.co.uk/>.

\section{Scottish papers}

The Aberdeen Journal

The Caledonian Mercury

The Perthshire Courier

The Inverness Journal and Northern Advertiser, 1811-1815, National Library of Scotland, CBWall.2/96

\section{English papers}

Bath Chronicle and Weekly Gazette

Bury and Norwich Post

Chelmsford Chronicle

Chester Chronicle

Chester Courant

Derby Mercury

Exeter Flying Post

Gloucester Journal

Hampshire Chronicle

Hampshire Telegraph

Hereford Journal

Hull Packet

Ipswich Journal

Kentish Gazette

Lancaster Gazette

Leeds Intelligencer

London Courier and Evening Gazette

Manchester Mercury

Morning Chronicle

Morning Post

Newcastle Courant

Norfolk Chronicle

Northampton Mercury

Northampton Mercury

Oxford Journal

Reading Mercury

Salisbury and Winchester Journal

Staffordshire Advertiser

Stamford Mercury

Sussex Advertiser 
The Cumberland Pacquet and Ware's Whitehaven Advertiser

The Times

York Herald

\section{Colonial correspondence and instructions (National Archives Canada)}

CO42 - volume 15 to 22 (1781-1821).

Q (Upper and Lower Canada) - volumes 26 to $136 \mathrm{~A}$ and 278 to $318 \mathrm{~A}$ (1783-1816).

A (Nova Scotia and Cape Breton) - volumes 105 to 155 (1784-1815).

RG7 G8B (New Brunswick) - volumes 1 to 5 (1784-1820).

RG7 G8D (Prince Edward's Island) - volumes 1 to 4 (1771-1817).

"Petition for a House of Assembly", 24th November 1784, in A. Shortt \& A. G. Doughty (eds) (1906), Documents Relating to the Constitutional History of Canada, 1759-1791, Ottawa: S. E. Dawson.

DoughtY Arthur (ed.) (1905), Report Concerning the Canadian Archives for the Year 1904, Ottawa:

E. Dawson, printer to the King's Most Excellent Majesty, 261-285.

DoughtY Arthur (ed.) (1906), Report Concerning the Canadian Archives for the Year 1905, Ottawa:

E. Dawson, printer to the King's Most Excellent Majesty, 3-69.

\section{Works on British North America}

A Free and Candid Review of a Tract entitled "Observations on the Commerce of the American States" (1784), London: Lowndes.

ANDERSON David (1814), Canada: Or a View of the Importance of the British American Colonies, London: Richardson.

ATCHESON Nathaniel (1808), American Encroachments on British Rights: Or Observations on the Importance of the British North American Colonies, London: J. Butterworth.

Boulton D’Arcy (1805), Sketch of His Majesty's Province of Upper Canada, London: Rickaby.

CHAMPION Richard (1784), Considerations on the Present Situation of Great Britain and the United States of America, London.

Collection of Interesting and Important Reports and Papers on the Navigation and Trade of Great Britain, Ireland, and the British Colonies in the West Indies and America (1807), printed by order of the Society of Ship Owners of Great Britain.

Colquhoun Patrick (1814), A Treatise on the Wealth, Power, and Resources of the British Empire, London: Joseph Mawman.

Concessions to America, the Bone of Britain: Or the Cause of the Present Distressed Situation of the British Colonial and Shipping Interests Explored (1807), London: Richardson.

EDWARDS Bryan (1793), The History Civil and Commercial of the British Colonies in the West Indies (vol. II), London: Stockdale.

LYMBURNER Adam (1788), A Review of the Government and Grievances of the Province of Quebec, since the Conquest of It by the British Arms, London: Stockdale and Richardson.

MoNk James (1789), State of the Present Form of Government of the Province of Quebec, London: Debrett. 
Remarks on the Climate, Produce and Natural Advantage of Nova Scotia (n.d.), London: Debrett. SHEFFIELD Lord John (1784), Observations on the Commerce of the American States, London: Debrett. SHEFFIELD Lord John (1804), Strictures on the Necessity of Inviolably Maintaining the Navigation and Colonial System of Great Britain, London: J. Debrett.

STEVENSON John (1784), An Address to Bryan Edwards, London: Nicoll.

STEWART John (1806), An Account of Prince Edward Island, London: Winchester \& Son.

\section{Secondary Sources}

BicКнАм Troy (2013), “American Indians in the British Imperial Imagination, 1707-1815”, S. Foster (ed), British North America in the Seventeenth and Eighteenth Centuries, Oxford: Oxford University Press, 227-254.

BLACK Jeremy (1992), “The Eighteenth Century British Press”, D. Griffiths (ed.), The Encyclopaedia of the British Press, 1422-1992, Basingstoke: Macmillan Press, 13-23.

BUCKNER Phillip (ed.) (2008), Canada and the British Empire, Oxford: Oxford University Press.

Colley Linda (1992), Britons, Forging the Nation 1707-1837, New Haven and London: Yale University Press.

CowAN Helen (1961), British Emigration to British North America, Toronto: University of Toronto Press.

EDWARDS Gail \& SALTMAN Judith (2010), Picturing Canada: A History of Canadian Children's Illustrated Books and Publishing, Toronto: University of Toronto Press.

ERRINGTON Jane (1987), The Lion, the Eagle and Upper Canada: A Developing Colonial Ideology, Kingston and Montreal: McGill-Queen's University Press.

HALL Catherine (2008), "Culture and Identity in Imperial Britain”, S. Stockwell (ed.), The British Empire: Themes and Perspectives, Oxford: Blackwell Publishing, 199-217.

JASANOFF Maya (2010), "Revolutionary Exiles: The American Loyalists and the French Emigré Diaspora", D. Armitage \& S. Subrahmanyan (eds), The Age of Revolution in Global Context, c. 17601840, Basington and New York: Palgrave Macmillan, 37-58.

JASANOFF Maya (2011), Liberty's Exiles: American Loyalists in the Revolutionary World, New York and Toronto: Alfred A. Knopf, ebook.

KING Ed (2007), “British Newspapers 1800-1860”, British Library Newspapers, Detroit, Gale Cengage Learning, <www.gale.com/intl/essays/ed-king-british-newspapers-1800-1860> (4 June 2021).

KITZAN Laurence (2001), Victorian Writers and the Image of Empire: The Rose-Colored Vision, Wesport (CN) and London: Greenwood Press.

KNORR Klaus E. (1944), British Colonial Theories, 1570-1850, Toronto: Toronto University Press.

KNOWLES Valerie (2006), Strangers at Our Gate: Canadian Immigration and Immigration Policy, 1540-2007, Toronto: Dundern Press.

LACROIX Jean-Michel (2016), Histoire du Canada : des origines à nos jours, Paris: Éditions Tallandier.

LINTEAU Paul-André (2014), Histoire du Canada, Paris: Presses universitaires de France, eBook. 
MARSHALl P. J. (2015), Remaking the British Atlantic: The United States and the British Empire after American Independence, Oxford: Oxford University Press.

MiLls David (1988), Idea of Loyalty in Upper Canada, 1784-1850, Kingston and Montreal: McGillQueen's University Press.

MiLOBAR David (1990), “Conservative Ideology, Metropolitan Government and the Reform of Quebec, 1782-1791", The International History Review, 12(1), 45-64.

Powell David (2002), Nationhood and Identity: The British State since 1800, London and New York: IB Tauris and Company Ltd.

SCHWEIZER Karl W. (2006), "Newspapers, Politics and Public Opinion in the Later Hanoverian Era", Parliamentary History, 25(1), 32-48.

SEELEY Sir John Robert (1883), The Expansion of England: Two Courses of Lectures, Kindle book.

Simpson-Housley Paul \& Norcliffe Glen (eds) (1992), A Few Acres of Snow, Literary and Articstic Images of Canada, Toronto and Oxford: Dundurn Press.

TAFT MANNING Helen (1933), British Colonial Government after the American Revolution, 1782-1820, New Haven: Yale University Press.

TAYLOR M. Brook (1989), Promoters, Patriots, and Partisans, Historiography in Nineteenth-Century English Canada, Toronto: University of Toronto Press.

THE TIMEs (1935), A Newspaper History, 1785-1935, Reprinted from the 150th Anniversary Number of The Times, London: The Times Publishing Company Ltd.

Williams Kevin (2010), Read All About It! A History of the British Newspaper, New York: Routledge.

WILSON Kathleen (1994), "Empire of Virtue: The Imperial Project and Hanoverian Culture, c. 17201785”, L. Stone (ed.), An Imperial State at War: Britain From 1689-1815, London: Routledge, 128-164.

\section{NOTES}

1. And, until recently, the historiography of the British empire also tended to spread the idea that Britons felt a lack of interest British North America, and even disgust towards the Empire as whole, after 1783 (Seeley, 1883: chapter 1,8; Taft Manning, 1933: 3; Knorr, 1944: 21; Powell, 2002: 104).

2. Amongst these reforms were: the creation of the Province of New Brunswick in 1784, the creation of a Bishop Sea in 1786, the nomination of a Governor General that same year and the Canada Act (which created the provinces of Upper and Lower Canada and endowed them with legislative assemblies) in 1791.

3. For instance, Vincent Harlow in the 1950s and, more recently, P. J. Marshall conclude their studies of British policies for, and relationship with, British North America in the early 1790s, while Canada is only a negligible part of C. A. Bayly's work on the imperialism of Britain between 1783 and 1830. Cf. Harlow V. T. (1952-1964), The Founding of the Second British Empire, 1763-1793 (2 volumes), London: Longman; Bayly C. A. (1989), Imperial Meridian: The British Empire and the World, 1780-1830, New York: Longman; Marshall P. J. (2015), Remaking the British Atlantic: The United States and the British Empire after American Independence, Oxford: Oxford University Press.

4. See also Cain P. J. \& Hopkins A. G. (1993), British Imperialism: Innovation and Expansion, 1688-1914, London and New York: Longmans, 46 for the ubiquity of imperialism. 
5. The studies on the representations of Canada by Simpson-Housley and Norcliffe (1992) and Edwards and Saltman (2010) focus on the later Nineteenth century.

6. In my PhD thesis, I have also analysed other published sources, such as parliamentary debates, economic works, pamphlets written by promoters, travel writers, reviews and magazines. The results of such research are similar to those presented in this paper.

7. See also: Ipswich Journal, 7 Aug. 1784; Kentish Gazette, 23 Mar. 1790; Hereford Journal, 24 Mar. 1790; Stamford Mercury, 26 Mar. 1790; Norfolk Chronicle, 27 Mar. 1790, 12 Sept. 1795.

8. See also for example: The Gentleman's Magazine, vol. 54, 1784: 867; vol. 55, 1785: 69; vol. 62, 1792: 270; The Scots Magazine, vol. 61, 1799: 231; vol. 63, 1801: 550-553.

9. See also for example: Stamford Mercury, 22 Jan. 1796; Caledonian Mercury, 21 Jan. 1796.

10. It is however interesting to note that a year later, another contributor showed great enthusiasm for the massive colonisation of British North America (The Annual Review, vol. 4, 1806: 332-334).

11. This article was circulated in the local press. See: Kentish Gazette, 4 Sept. 1784; Northampton Mercury, 6 Sept. 1784; Manchester Mercury, 7 Sept. 1784; Hereford Journal, 9 Sept. 1784.

12. Hundreds of examples can be found throughout the period under study. Only a few have been chosen here in order to show that articles on these topics were published in London and local papers all over the period between 1783 and 1815.

- For the fertility of the soils: The Times, 5 Oct. 1785, 9 Aug. 1786, 30 Sept. 1791, 7 Dec. 1791, 4 Jul. 1807; Chester Courant, 4 Aug. 1795, Leeds Intelligencer, 3 Oct. 1796; Chester Chronicle, 2 Feb. 1798; Hampshire Chronicle, 13 Sept. 1802; Caledonian Mercury, 25 Jul. 1805.

- For the fisheries: The Times, 13 Nov. 1786, 25 Aug. 1787, 18 Dec. 1799.

- For the fur trade: The Times, 7 Oct. 1788; Northampton Mercury, 28 Jan. 1797; Oxford Journal, 28 Jan. 1797; Caledonian Mercury, 30 Jan. 1797; Chester Chronicle, 2 Feb. 1798.

- For ores: The Times, 25 Aug. 1787; Bath Chronicle and Weekly Gazette, 8 Aug. 1793; Leeds Intelligencer, 3 Oct. 1796; Hampshire Chronicle, 25 Oct. 1802; Hereford Journal, 2 Apr. 1806.

- For timber: Oxford Journal, 9 Oct. 1784; Reading Mercury, 11 Oct. 1784; Northampton Mercury, 11 Oct. 1784; Leeds Intelligencer, 12 Oct. 1784; The Times, 9 Aug. 1786, 9 Mar. 1811, 8 Apr. 1811.

13. These descriptions found in the press were shorter versions of the depictions of the colonies in the works published by the promoters of the Canadas and emigration thither. See for instance: Boulton (1805: 3-12); Stewart (1806: III-XIII); Atcheson (1808: XXIX-XLVII); Colquhoun (1814: 309).

14. See for example: The Gentleman's Magazine, vol.55, 1785: 71-72; vol.56, 1786: 437; Oxford Journal, 20 Jan. 1798; Caledonian Mercury, 4 Jan. 1796; Morning Post, 16 Feb. 1801; The Times, 12 Jul. 1803.

15. See for different types of examples: The Times, 25 Feb. 1790, 5 May 1812, 27 Mar. 1815; Caledonian Mercury, 12 Apr. 1794; Aberdeen Journal, 16 Dec. 1801.

16. A large number of examples can be found in the London and in the local press. See for example: The Times, 26 Dec. 1785, 30 Mar. 1787, 13 Nov. 1786, 11 Jul. 1787, 3 Jan. 1789, 27 May 1789, 16 Sept. 1791, 30 Jan. 1794; Kentish Gazette, 21 Aug. 1784, 30 Jul. 1790; Derby Mercury, 15 Sept. 1785; Manchester Mercury, 20 Sept. 1785; Oxford Journal, 24 Sept. 1785, 31 Jul. 1790; Hampshire Chronicle, 12 Dec. 1785, 2 Aug. 1790, 16 Dec. 1797; Manchester Mercury, 13 Dec. 1785, 26 Jan. 1790; Norfolk Chronicle, 7 Jan. 1786; Leeds Intelligencer, 10 Jan. 1786; Hereford Journal, 15 Apr. 1789; Leeds Intelligencer, 3 Aug. 1790, 17 Sept. 1795, 18 Sept. 1797; Ipswich Journal, 19 Sept. 1795; Caledonian Mercury, 2 Aug. 1790, 21 Sept. 1795; Stamford Mercury, 30 Jul. 1790, 22 Jul. 1796.

17. "Petition for a House of Assembly", 24th November 1784, in Shortt \& Doughty (1906: 505). Hare J. (1993), Aux origines du parlementarisme québécois, 1791-1793, Québec: Septentrion.

18. See also: Hereford Journal, 21 Apr. 1785; Kentish Gazette, 23 Apr. 1785; Caledonian Mercury, 23 Apr. 1785; Leeds Intelligencer, 26 Apr. 1785; Newcastle Courant, 30 Apr. 1785. Over the 1780s and 1790s, some dispatches, decisions and articles intended to show how to strengthen and 
ensure the attachment of the Canadians to the Crown (The Times, 24 May 1786, 8 Nov. 1786; Derby Mercury, 26 Dec. 1793; Hampshire Chronicle, 27 Jan. 1794).

19. This was particularly obvious after the Canada Act was implemented. See for instance: Leeds Intelligencer, 29 Apr. 1793; Caledonian Mercury, 10 Jun. 1793; Hampshire Chronicle, 1 Sept. 1794; Newcastle Courant, 15 Nov. 1794.

20. See also: The Gentleman's Magazine, vol. 83, part 2, 1813: 267-268, 488; vol. 85, 1815: 137.

21. In 1788 for instance, newspapers reported that the goods shipped from Canada amounted to a remittance of $£ 100,000$. Hereford Journal, 26 Nov. 1788; Bury and Norwich Post, 26 Nov. 1788; Caledonian Mercury, 27 Nov. 1788; Chelmsford Chronicle, 27 Nov. 1788; Stamford Mercury, 28 Nov. 1788; Oxford Journal, 29 Nov. 1788; Hampshire Chronicle, 1 Dec. 1788; Leeds Intelligencer, 2 Dec. 1788; Cumberland Pacquet, 3 Dec. 1788.

22. To quote one example amongst many, at the end of the year 1800, The Times published extracts of the debates for the encouragement of the fisheries of New Brunswick and Nova Scotia (The Times, 22 Nov., 28 Nov., 9 Dec 1800).

23. See also Oxford Journal, 11 Dec. 1790; Hampshire Chronicle, 13 Dec. 1790; Derby Mercury, 16 Dec. 1790; Sheffield Register, 17 Dec. 1790.

24. See also: Hull Packet, 14 Jan. 1800, 7 Apr. 1801, 20 Oct. 1801; Stamford Mercury, 21 Jan. 1803; Northampton Mercury, 22 Jan. 1803; Hampshire Chronicle, 24 Jan. 1803; Oxford Journal, 10 Dec. 1803; Hampshire Chronicle, 12 Dec. 1803; Hull Packet, 13 Dec. 1803; Aberdeen Journal, 14 Dec. 1803.

25. Because the redirection of migrants to the British colonies was encouraged by policies implemented by the British Government too. See my article "L'émigration écossaise vers l'Amérique du Nord britannique (c. 1783-1815) : vers une convergence des politiques du centre pour les périphéries", Études écossaises, no. 19, 2017, <https://doi.org/10.4000/etudesecossaises. 1209>.

26. See also: Northampton Mercury, 18 Feb. 1786; Oxford Journal, 18 Feb. 1786; Manchester Mercury, $21 \mathrm{Feb} .1786$; Leeds Intelligencer, 21 Feb. 1786.

27. See also: The Times, 15 Jan. 1799, 24 Sept. 1812; Hampshire Chronicle, 21 Sept. 1801.

\section{ABSTRACTS}

The ways Britons imagined and represented their British North American colonies after the loss of the thirteen colonies in 1783 is a theme that is largely under researched. Through the study of British newspapers, both London-based and local, this article aims at understanding what images and representations Britons had of their Canadian colonies from the end of the War of Independence to the end of the War of 1812. Such analysis shows British North America offered more than the image of "a few acres of snow". It also explores the manners in which those images of North America sprang from and contributed to the spreading of the imperial propaganda in the British public sphere.

La façon dont les Britanniques imaginaient et représentaient leurs colonies britanniques d'Amérique du Nord après la perte des treize colonies en 1783 est un thème largement sous-étudié. À travers l'étude de la presse britannique (tant les journaux basés à Londres que la presse locales), cet article cherche à comprendre quelles images et représentations les Britanniques avaient de leurs colonies canadiennes de la fin de la guerre d'Indépendance jusqu'à la fin de la guerre de 1812. Cette analyse montre que les représentations de l'Amérique du Nord 
britannique ne se limitaient pas à l'idée de « quelques arpents de neige ». Cette recherche explore également la manière dont ces images de l'Amérique du Nord étaient issues de la propagande impériale et comment elles contribuèrent à leur diffusion dans la sphère publique britannique.

INDEX

Mots-clés: représentations, Amérique du Nord britannique, presse britannique, propagande impériale, 1783-1815

Keywords: representations, British North America, British press, imperial propaganda, 17831815

\section{AUTHOR}

\section{ALICE LEMER-FLEURY}

Université de Nantes, CRHIA

alice.lemer@univ-nantes.fr 